\title{
Toxic shock syndrome
}

\section{Ryota Inokuchi, ${ }^{1,2}$ Yoshihiro Ueda, ${ }^{1}$ Tomohiro Sonoo, ${ }^{1}$ Naoki Yahagi ${ }^{1}$}

${ }^{1}$ Department of Emergency and Critical Care Medicine, The University of Tokyo Hospital, Tokyo, Japan

${ }^{2}$ Department of Emergency and Critical Care Medicine, JR General Hospital, Tokyo, Japan

\section{Correspondence to} Dr Ryota Inokuchi, inokuchi-r@h.u-tokyo.ac.jp

Accepted 19 February 2015

\section{DESCRIPTION}

A 30-year-old healthy man, on awakening, experienced shaking chill, general malaise and generalised redness on the skin. The previous day, he had been bitten on the right mandible by mosquitoes (figure 1). On admission, his temperature was $40.1^{\circ} \mathrm{C}$, pulse rate $140 \mathrm{bpm}$, blood pressure $80 /$ $50 \mathrm{~mm} \mathrm{Hg}$, respiratory rate $40 / \mathrm{min}$, oxygen saturation 100\% (10-L reservoir mask) and Glasgow Coma Scale score E2V5M6. Physical examination showed diffuse macular erythroderma (figure 2) without diarrhoea, muscle aches or blepharoconjunctivitis. Laboratory tests showed severe inflammation (white cell count $13500 / \mu \mathrm{L}$ and $\mathrm{C}$ reactive protein $182 \mathrm{mg} / \mathrm{L}$ ) and elevated hepatic enzymes. Other laboratory tests including urea, creatinine and creatine kinase were normal. Whole-body CT showed mosquito bite-induced cellulitis. A rapid group A streptococcus test, blood culture and cerebrospinal fluid culture were negative. We initiated aggressive fluid resuscitation, norepinephrine, meropenem (3 g/day) and clindamycin ( $1.2 \mathrm{~g} /$ day). Desquamation of the patient's hands was noted

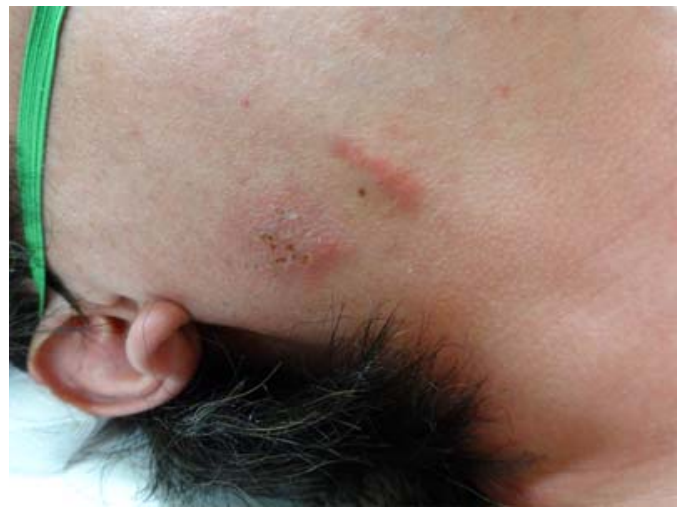

Figure 1 The site of the mosquito bites on the right mandible.

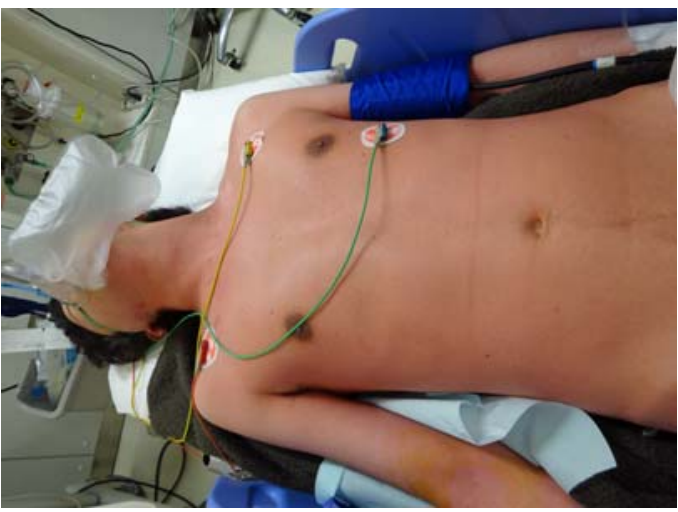

Figure 2 Erythematous maculopapular eruption on the entire body, similar to that noted in cases of sunburn.

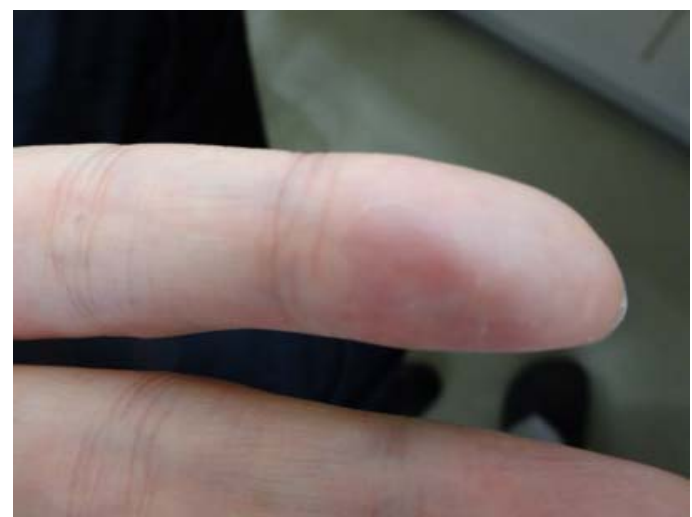

Figure 3 Desquamation of the finger.

7 days post-admission (figure 3). The changes in skin resolved within 2 weeks of illness onset.

Toxic shock syndrome (TSS) is extremely rare, it can cause acute, progressive illness-associated multiple organ failure. ${ }^{1}$ TSS is caused by exotoxins, produced by Staphylococcus aureus or group A streptococcus, but blood culture is positive in $<5 \%$ of staphylococcal TSS cases. ${ }^{12}$ There is no single test for TSS, so TSS is diagnosed based on clinical presentations. Thus, the physician should administer prompt antibiotic therapy to cover Staphylococcus aureus and group A streptococcus when TSS is suspected.

\section{Learning points}

- Typical symptoms of toxic shock syndrome (TSS) must be recognised by every physician because delay in adequate treatment results in poor outcome.

- Staphylococcus aureus and group A streptococcus infection should be mandatorily covered with initial, empirical antimicrobial treatment in these patients.

- The mosquito bite can cause TSS.

Contributors All the authors contributed to patient management. RI drafted the initial manuscript. All authors contributed to writing the manuscript.

\section{Competing interests None.}

Patient consent Obtained.

Provenance and peer review Not commissioned; externally pee reviewed.

\section{REFERENCES}

1 [No authors list]. Case definitions for infectious conditions under public health surveillance. Centers for Disease Control and Prevention. MMWR Recomm Rep 1997;46:1-55.

2 Lappin E, Ferguson AJ. Gram-positive toxic shock syndromes. Lancet Infect Dis 2009;9:281-90. 


\section{Images in...}

Copyright 2015 BMJ Publishing Group. All rights reserved. For permission to reuse any of this content visit http://group.bmj.com/group/rights-licensing/permissions.

BMJ Case Report Fellows may re-use this article for personal use and teaching without any further permission.

Become a Fellow of BMJ Case Reports today and you can:

- Submit as many cases as you like

- Enjoy fast sympathetic peer review and rapid publication of accepted articles

- Access all the published articles

- Re-use any of the published material for personal use and teaching without further permission

For information on Institutional Fellowships contact consortiasales@bmjgroup.com

Visit casereports.bmj.com for more articles like this and to become a Fellow 